\title{
Emerging HIV Drug Resistance in the Resource-Poor World: Challenges and Strategies
}

\author{
Koosha Paydary ${ }^{1,2}$, Shooka Esmaeeli ${ }^{1,2}$, SeyedAhmad SeyedAlinaghi ${ }^{1}$, Pouria Rouzrokh ${ }^{2}$ and Sahra Emamzadeh-Fard ${ }^{1,2 *}$ \\ ${ }^{1}$ Iranian Research Center for HIVIAIDS (IRCHA), Tehran University of Medical Sciences (TUMS), Tehran, Iran \\ '2Students' Scientific Research Center (SSRC), Tehran University of Medical Sciences (TUMS), Tehran, Iran
}

\section{Determining Factors of Anti-retroviral Drug Resistance}

At the end of 2011, more than 8 million People Living with HIV (PLWH) were receiving Anti-retroviral Therapy (ART) in low- and middle-income countries [1]. Accordingly, the advent and extensive use of Highly Active Anti-retroviral Therapy (HAART) has dramatically reduced the mortality and morbidity associated with the HIV infection worldwide [2]. However, many factors such as missing doses of medications, interruptions in ART and mono-therapy in the pre-HAART era may ultimately result in clinical drug resistance and virologic failure [3-8].

Many virological, immunological and pharmacological factors may play role in the development of Anti-retroviral Drug Resistance (ADR). First, the rate of viral duplication and turnover associated with HIV infection is too high [4,9-11]. In addition, circulating viral quasispecies may be extremely heterogonous. In fact, the lack of proofreading and an infidel reverse transcriptase can give rise to a genotypically heterogonous horde of circulating viral quasi-species soon after the infection has been established $[12,13]$. It is noteworthy that developing ADR requires accumulation of genomic changes within host bodily systems [4,14-18]. The consequent genetic diversity may result in the phenotypic drug resistance to various ART agents. Therefore, HIV shows unpredictable patterns of drug resistance in vivo, mainly due to its different adaptation mechanisms to local cellular environments, drugs' varying selective pressure, immune system reactions and many other virologic factors $[19,20]$.

The wide availability of HAART may also be associated with the emergence of new HIV variants with less sensitivity to anti-retroviral drugs. Correspondingly, some authors believe that the evolution of ADR is an inevitable consequence of extensive HAART administration. For instance, Palumbi claimed that the extensive uses of prescribed regimens are accelerating retroviral evolutionary patterns toward the selection of mutant variants, especially in developed nations [21]. On the other hand, if HAART is discontinued in a patient who has developed drug resistance, the resistant mutants will be replaced with the wild type viral strain as a result of omitting drug selective pressure. However, there may be a chance to find a minority of drug resistant mutants by allele-specific Polymerase Chain Reaction (PCR) among such patients. By initiating the subsequent therapy that can seemingly induce a complete suppression in the viral load, the resistant mutants may persist at low levels in long-time infected cells [22-27].

Non-adherence or low-adherence of patients to ART regimens should also be noted as a determining factor of ADR. Also, limited access to HAART in non-industrialized nations and lack of optimal therapy after a previously failed treatment attempt have been reported as establishing factors of ADR worldwide. Many ADR infections have resulted from mono-therapy with only one specific drug type especially in the developing nations [23,26,28-30].

\section{Prevalence and Global Trends of ADR}

The World Health Organization (WHO) has reported that the prevalence of HIV drug resistance has been around 7\% between the years 2003 and 2010 worldwide. With the expansion of ART coverage achieved over the last years, increasing prevalence of HIV drug resistance has been reported, particularly to Non-Nucleaoside Reverse Transcriptase Inhibitors (NNRTI) [31-33]. Reports suggest that 10-17\% of naïve HIV patients in Australia, Japan, United States and Europe are infected with resistant viral strains to at least one of the ART agents $[1,25]$.

In addition to the previous studies, many other surveys have been conducted to report the prevalence of ADR worldwide [34,35]. In general, the prevalence of transmitted HIV drug resistance (TDR) has shown an increasing trend in the developed world [36]; however, recently conducted surveys in Western Europe and United States have shown that the trend of TDR has become steady after its ascending pattern in such regions of the world [37-39]. The increasing efficacy of HAART and the development of new generation ARV agents have been proposed as possible reasons for this trend [40-42]. In a study conducted in a private clinic in San Francisco, the authors documented stable prevalence of ADR between the years 2004 to 2006. HIV drug resistance was associated with being MSM (Men who have Sex with Men), positive history of Sexually Transmitted Infections (STI), monotherapy and the use of NNRTIs. Based on this survey, the overall prevalence of ADR during the three years was 13\% [33].

Based on previous reports from some developed countries, single resistance mutations might be transmitted to almost $10-15 \%$ of the newly infected patients $[43,44]$. Although there is paucity of data about TDR trends in many developing nations, future therapeutic options might be highly limited due to the transmission of multi-drug resistant variants in such regions. In a survey performed in Spain during 19962010, TDR prevalence was $9.7 \%$ (10.6\% for Spanish, $8.4 \%$ for SubSaharan Africans (SSA) and 7.9\% for Central-South Americans (CSA) [36]. Regarding each region, the highest prevalence rates were found to Protease Inhibitors (PI) in Spanish (3.1\%), to NNRTI in SSA (6.5\%) and to NRTI in both Spanish and SSA (6.5\%) patients.

Generally, the global TDR rate has shown a decline from $11.3 \%$ in $2004-2006$ to $8.4 \%$ in $2007-2010$ periods, especially among developed nations [36].Thereby, there has been a decrease in the rate of transmitted NNRTI and PI resistance over time within the developed

*Corresponding author: Sahra Emamzadeh-Fard, Iranian Research Center for HIVIAIDS (IRCHA), Imam Khomeini Hospital, Keshavarz BIvd, Tehran, Iran, Tel: +982166947984; E-mail: sahra_emamzadeh@yahoo.com

Received February 08, 2013; Accepted March 11, 2013; Published March 21 2013

Citation: Paydary K, Esmaeeli S, SeyedAlinaghi S, Rouzrokh P, Emamzadeh-Fard S (2013) Emerging HIV Drug Resistance in the Resource-Poor World: Challenges and Strategies. J AIDS Clinic Res S5: 006. doi:10.4172/2155-6113.S5-006

Copyright: ( 2013 Paydary K, et al. This is an open-access article distributed under the terms of the Creative Commons Attribution License, which permits unrestricted use, distribution, and reproduction in any medium, provided the original author and source are credited. 
world [29,34,35]. However, a recent review of ADR among Asian countries revealed that there is no convincing evidence supporting the idea that TDR is gradually increasing in developing Asian nations [45]. Additionally, many countries -either developed or developinghave undertaken steps in order to increase the accessibility of HAART; nevertheless, with emerging drug resistance they have shifted the applied regimens. Although such approach has facilitated the stalling of ADR development, it has been accompanied by a considerably high expenditure of resources. Nonetheless, maintaining a low-level of ADR in developed countries might be closely related to its control in the developing world $[34,36]$.

\section{Strategies Adhered by the Developed World}

In order to combat the developing ADR, various strategies have been implemented worldwide, most of which focus on the increasing patients' adherence. Also, developed nations have most recently applied the widespread use of drug resistance genotyping to support case management and treatment monitoring [37]. Although genotyping is expensive and requires certain facilities, the monitoring of patients is comparatively efficacious and may be successfully used to timely identify the gaps in service delivery in order to take the corrective action and minimize the emergence of ADR. In addition, most of these reports mentioned that ADR is higher among infrequently monitored patients compared to patients that are more intensively monitored [26,38]. Table 1 briefly shows the specific strategies that have been adhered by the developed world in order to combat emerging ADR according to the conducted surveys.

\section{Application for the Resource-poor World}

In order to identify the policies and strategies which stall the development of ADR in the developing world, we should bear in mind that many ADR determining factors in the developing settings may be dissimilar to that of the developed world. For example, the societal determinants such as migration, incarceration, epidemiology of addiction or other high risk behaviors or even the dispersal of most- at-risk populations extensively vary among the two worlds. Thereby, one may conclude that most of the effectively implemented policies in the developed world may not be comparatively applicable within the developing world. In this regard, genotyping surveillance systems and tight patient monitoring may not be ideally applicable especially in circumstances were HIV is prevalent and lack of sufficient healthcare workers exists. For example, studies have debated the applicability of baseline resistance testing in Asian settings [45]. In fact, ADR in the developing world seems to be best brawled back by conducting simple strategies that most likely target the behavioral components and primary healthcare infrastructure. For example, reports indicate that unregulated or poorly supervised ART programs may result in the rapid ADR development among resource-poor nations. Budgetary and logistical problems further complicate the delivery of adequate ART regimens and induction of sufficient viral suppression. Correspondingly, interventions that increase the knowledge with regard to the importance of adherence and behavioral amendments (i.e. consistent use of barriers) among patients are of utmost importance under such circumstances [45]. Additionally, adoption to appropriate drug regimens as the first-line therapy would be extremely important to prevent development and transmission of ADR. Also, switching to second-line treatment combinations seems to be effective for the majority of patients failing first-line therapy [40]. Moreover, viral load monitoring (VLM) can be used as an indicator for treatment switch after the first regimen failure. Reduced resistance in those with frequent monitoring suggests that VLM not only detects poor adherence, but also can detect the gaps in service delivery and program performance [38]. In conclusion, the lessons learnt from the evolution and monitoring of ADR phenomenon in the developed world indicate that simple long-term strategies might be more effective if implemented focusing on patients' adherence as well as increasing ART access for all PLWH. Amending primary healthcare infrastructure and conducting simple ADR surveillance systems parallel to the administration of appropriate drug regimens as the first-line therapy are necessary to prevent the

\begin{tabular}{|c|c|c|}
\hline Authors & Declared/Assessed Strategies & Country and Date \\
\hline $\begin{array}{l}\text { Shafer RW et al. [26] } \\
\text { Dybul M et al. [46] }\end{array}$ & $\begin{array}{l}\text { Switching the classes of drugs as the first reaction to resistance and Applying resistance assays to } \\
\text { avoid unnecessary drugs administration. }\end{array}$ & USA, 2002- USA, 2002 \\
\hline $\begin{array}{l}\text { Clavel F et al. [4] } \\
\text { Cvetkovic RS et al. [47] } \\
\text { Di Giambendetto S et al. [48] } \\
\text { Shafer RW et al. [26] }\end{array}$ & $\begin{array}{l}\text { Applying new drugs, for salvage or rescue therapy, that can be achieved by using agents with } \\
\text { increased potency or better pharmacokinetic properties or by using novel classes (i.e. fusion } \\
\text { inhibitors) which are not susceptible to cross-resistance. }\end{array}$ & $\begin{array}{l}\text { France, 2004- New Zealand, } \\
\text { 2003- Italy, 2009- USA, } 2002\end{array}$ \\
\hline Buendia P et al. [28] & $\begin{array}{l}\text { Predicting the development pathways of drug resistance with genotype-based prediction computer } \\
\text { systems by using the patient's clonal (pyro-) sequences at the beginning of therapy and failure points }\end{array}$ & USA, 2009 \\
\hline Ji H et al. [49] & $\begin{array}{l}\text { Selecting the best drug combination for national treatment programs by determining the prevalence } \\
\text { of drug resistance mutations in both protease and reverse transcriptase inhibitors through using Pyro- } \\
\text { sequencing }\end{array}$ & Canada, 2010 \\
\hline Yebra G et al. [36] & $\begin{array}{l}\text { Conducting specific drug resistance surveillance tools among immigrants in order to prevent probable } \\
\text { therapeutic failures, especially to NNRTIs. }\end{array}$ & Spain, 2011 \\
\hline $\begin{array}{l}\text { Trevino A et al. [50] } \\
\text { Imaz A et al. [51] } \\
\text { Tang MW et al. [52] }\end{array}$ & $\begin{array}{l}\text { Recommending not to apply commercial drug resistance tests before starting drug therapy, but to } \\
\text { apply them at failure points, in order to increase the success rate of subsequent salvage therapy } \\
\text { based on appropriate drug combination. }\end{array}$ & $\begin{array}{l}\text { Spain, 2011-Spain, 2012-USA, } \\
2012\end{array}$ \\
\hline Bercoff DP et al. [53] & $\begin{array}{l}\text { Identifying the component of viral genome which can potentially evolve resistance properties against } \\
\text { an agent for determining the more vigorous therapeutic options }\end{array}$ & Belgium, 2010 \\
\hline $\begin{array}{l}\text { Truong HM KT et al. [32] } \\
\text { Temereanca A EL et al. [[54] } \\
\text { Vercauteren J WA et al. [41] } \\
\text { Pingen M et al. [55] }\end{array}$ & $\begin{array}{l}\text { Using genotyping resistance testing in ARV-naïve HIV positive patients; in order to identify regimens } \\
\text { with vigorous genetic barrier to prevent failure of first line therapy. }\end{array}$ & $\begin{array}{l}\text { Netherland, 2011-Europe and } \\
\text { Israel, 2009-Romany, 2011- } \\
\text { USA, } 2011\end{array}$ \\
\hline
\end{tabular}

Table 1: Some of the recently published studies that have targeted the efficacy and plausibility of various strategies in the era of anti-retroviral drug resistance in the developed world are presented. 
Citation: Paydary K, Esmaeeli S, SeyedAlinaghi S, Rouzrokh P, Emamzadeh-Fard S (2013) Emerging HIV Drug Resistance in the Resource-Poor World: Challenges and Strategies. J AIDS Clinic Res S5: 006. doi:10.4172/2155-6113.S5-006

evolution of ADR under such circumstances.

\section{References}

1. WHO (2012) HIV Drug resistance report.

2. Roberts JD, Bebenek K, Kunkel TA (1988) The accuracy of reverse transcriptase from HIV-1. Science 242: 1171-1173.

3. Preston BD, Poiesz BJ, Loeb LA (1988) Fidelity of HIV-1 reverse transcriptase. Science 242: 1168-1171.

4. Clavel F, Hance AJ (2004) HIV drug resistance. N Engl J Med 350: 1023-1035.

5. Van Vaerenbergh $\mathrm{K}$ (2001) Study of the impact of HIV genotypic drug resistance testing on therapy efficacy. Verh K Acad Geneeskd Belg 63: 447-473.

6. Richman DD (2001) HIV chemotherapy. Nature 410: 995-1001.

7. Piacenti FJ (2006) An update and review of antiretroviral therapy. Pharmacotherapy 26: 1111-1133.

8. van Marle G, Church DL, Nunweiler KD, Cannon K, Wainberg MA, et al. (2010) Higher levels of Zidovudine resistant HIV in the colon compared to blood and other gastrointestinal compartments in HIV infection. Retrovirology 7: 74

9. Haase AT (1999) Population biology of HIV-1 infection: viral and CD4+ T cell demographics and dynamics in lymphatic tissues. Annu Rev Immunol 17: 625656 .

10. Ho DD, Neumann AU, Perelson AS, Chen W, Leonard JM, et al. (1995) Rapid turnover of plasma virions and CD4 lymphocytes in HIV-1 infection. Nature 373: 123-126.

11. Wei X, Ghosh SK, Taylor ME, Johnson VA, Emini EA, et al. (1995) Viral dynamics in human immunodeficiency virus type 1 infection. Nature 373: 117-122.

12. Roberts JD, Bebenek K, Kunkel TA (1988) The accuracy of reverse transcriptase from HIV-1. Science 242: 1171-1173.

13. Preston BD, Poiesz BJ, Loeb LA (1988) Fidelity of HIV-1 reverse transcriptase. Science 242: 1168-1171.

14. Banke S, Lillemark MR, Gerstoft J, Obel N, Jørgensen LB (2009) Positive selection pressure introduces secondary mutations at Gag cleavage sites in human immunodeficiency virus type 1 harboring major protease resistance mutations. J Virol 83: 8916-8924.

15. García-Lerma JG, Maclnnes H, Bennett D, Weinstock H, Heneine W (2004) Transmitted Human Immunodeficiency Virus Type 1 Carrying the D67N or K219Q/E Mutation Evolves Rapidly to Zidovudine Resistance in vitro and Shows a High Replicative Fitness in the Presence of Zidovudine. J Virol 78: 7545-7552.

16. Iversen AK, Shafer RW, Wehrly K, Winters MA, Mullins JI, et al. (1996) Multidrug-resistant human immunodeficiency virus type 1 strains resulting from combination antiretroviral therapy. J Virol 70: 1086-1090.

17. Bull JJ, Sanjuán R, Wilke CO (2007) Theory of lethal mutagenesis for viruses. J Virol 81: 2930-2939.

18. Miller V, de Béthune MP, Kober A, Stürmer M, Hertogs K, et al. (1998) Patterns of resistance and cross-resistance to human immunodeficiency virus type 1 reverse transcriptase inhibitors in patients treated with the nonnucleoside reverse transcriptase inhibitor loviride. Antimicrob Agents Chemother 42: 31233129.

19. Kapoor A, Shapiro B, Shafer RW, Shulman N, Rhee SY, et al. (2008) Multiple independent origins of a protease inhibitor resistance mutation in salvage therapy patients. Retrovirology 5: 7.

20. Coffin JM (1995) HIV population dynamics in vivo: implications for genetic variation, pathogenesis, and therapy. Science 267: 483-489.

21. Palumbi SR (2001) Humans as the world's greatest evolutionary force. Science 293: $1786-1790$.

22. UK Collaborative Group on HIV Drug Resistance; UK Collaborative HIV Cohort Study; UK Register of HIV Seroconverters (2007) Evidence of a decline in transmitted HIV-1 drug resistance in the United Kingdom. AIDS 21: 1035-1039.

23. Wang D, Hicks CB, Goswami ND, Tafoya E, Ribeiro RM, et al. (2011) Evolution of drug-resistant viral populations during interruption of antiretroviral therapy. $\mathrm{J}$ Virol 85: 6403-6415.

24. Booth CL, Geretti AM (2007) Prevalence and determinants of transmitted antiretroviral drug resistance in HIV-1 infection. J Antimicrob Chemother 59: 1047-1056.

25. Richman DD, Morton SC, Wrin T, Hellmann N, Berry S, et al. (2004) The prevalence of antiretroviral drug resistance in the United States. AIDS 18: 1393-1401.

26. Shafer RW (2002) Genotypic testing for human immunodeficiency virus type 1 drug resistance. Clin Microbiol Rev 15: 247-277.

27. Mousavi SM, Hamkar R, Gouya MM, Safaie A, Zahraei SM, et al. (2010) Surveillance of HIV drug resistance transmission in Iran: experience gained from a pilot study. Arch Virol 155: 329-334.

28. Buendia P, Cadwallader B, DeGruttola V (2009) A phylogenetic and Markov model approach for the reconstruction of mutational pathways of drug resistance. Bioinformatics 25: 2522-2529.

29. SPREAD programme (2008) Transmission of drug-resistant HIV-1 in Europe remains limited to single classes. AIDS 22: 625-635.

30. Weinstock HS, Zaidi I, Heneine W, Bennett D, Garcia-Lerma JG, et al. (2004) The epidemiology of antiretroviral drug resistance among drug-naive HIV-1infected persons in 10 US cities. J Infect Dis 189: 2174-2180.

31. WHO (2012) The first WHO report on HIV drug resistance.

32. Truong HM, Kellogg TA, McFarland W, Louie B, Klausner JD, et al. (2011) Sentinel surveillance of HIV-1 transmitted drug resistance, acute infection and recent infection. PLoS One 6: e25281.

33. Wheeler WH, Ziebell RA, Zabina H, Pieniazek D, Prejean J, et al. (2010) Prevalence of transmitted drug resistance associated mutations and HIV-1 subtypes in new HIV-1 diagnoses, U.S.-2006. AIDS 24: 1203-1212.

34. Hecht FM, Grant RM, Petropoulos CJ, Dillon B, Chesney MA, et al. (1998) Sexual transmission of an HIV-1 variant resistant to multiple reversetranscriptase and protease inhibitors. N Engl J Med 339: 307-311.

35. Grant RM, Hecht FM, Warmerdam M, Liu L, Liegler T, et al. (2002) Time trends in primary HIV-1 drug resistance among recently infected persons. JAMA 288: 181-188.

36. Yebra G, de Mulder M, Pérez-Elías MJ, Pérez-Molina JA, Galán JC, et al. (2011) Increase of transmitted drug resistance among HIV-infected subSaharan Africans residing in Spain in contrast to the native population. PLoS One 6: e26757.

37. Little SJ, Holte S, Routy JP, Daar ES, Markowitz M, et al. (2002) Antiretroviraldrug resistance among patients recently infected with HIV. N Engl J Med 347: 385-394.

38. Masquelier B, Bhaskaran K, Pillay D, Gifford R, Balestre E, et al. (2005) Prevalence of transmitted HIV-1 drug resistance and the role of resistance algorithms: data from seroconverters in the CASCADE collaboration from 1987 to 2003. J Acquir Immune Defic Syndr 40: 505-511.

39. UK Collaborative Group on Monitoring the Transmission of HIV Drug Resistance (2001) Analysis of prevalence of HIV-1 drug resistance in primary infections in the United Kingdom. BMJ 322: 1087-1088.

40. Bannister WP, Cozzi-Lepri A, Clotet B, Mocroft A, Kjaer J, et al. (2008) Transmitted drug resistant HIV-1 and association with virologic and CD4 cell count response to combination antiretroviral therapy in the EuroSIDA Study. J Acquir Immune Defic Syndr 48: 324-333.

41. Vercauteren J, Wensing AM, van de Vijver DA, Albert J, Balotta C, et al. (2009) Transmission of drug-resistant HIV-1 is stabilizing in Europe. J Infect Dis 200: 1503-1508.

42. Bartmeyer B, Kuecherer C, Houareau C, Werning J, Keeren K, et al. (2010) Prevalence of transmitted drug resistance and impact of transmitted resistance on treatment success in the German HIV-1 Seroconverter Cohort. PLoS One 5: e12718.

43. Yerly S, Kaiser L, Race E, Bru JP, Clavel F, et al. (1999) Transmission of antiretroviral-drug-resistant HIV-1 variants. Lancet 354: 729-733.

44. Boden D, Hurley A, Zhang L, Cao Y, Guo Y, et al. (1999) HIV-1 drug resistance in newly infected individuals. JAMA 282: 1135-1141.

45. Sohn AH, Srikantiah P, Sungkanuparph S, Zhang F (2013) Transmitted HIV drug resistance in Asia. Curr Opin HIV AIDS 8: 27-33. 
Citation: Paydary K, Esmaeeli S, SeyedAlinaghi S, Rouzrokh P, Emamzadeh-Fard S (2013) Emerging HIV Drug Resistance in the Resource-Poor World: Challenges and Strategies. J AIDS Clinic Res S5: 006. doi:10.4172/2155-6113.S5-006

46. Dybul M, Fauci AS, Bartlett JG, Kaplan JE, Pau AK (2002) Guidelines for using antiretroviral agents among HIV-infected adults and adolescents. MMWR Recomm Rep 137: 381-433.

47. Cvetkovic RS, Goa KL (2003) Lopinavir/ritonavir: a review of its use in the management of HIV infection. Drugs 63: 769-802.

48. Di Giambenedetto S, Torti C, Prosperi M, Manca N, Lapadula G, et al (2009) Effectiveness of antiretroviral regimens containing abacavir with tenofovir in treatment-experienced patients: predictors of virological response and drug resistance evolution in a multi-cohort study. Infection 37: 438-444.

49. Ji H, Massé N, Tyler S, Liang B, Li Y, et al. (2010) HIV drug resistance surveillance using pooled pyrosequencing. PLoS One 5: e9263.

50. Treviño A, de Mendoza C, Caballero E, Rodríguez C, Parra P, et al. (2011) Drug resistance muta.tions in patients infected with HIV-2 living in Spain. J Antimicrob Chemother 66: 1484-1488.
51. Imaz A, Olmo M, Peñaranda M, Gutiérrez F, Romeu J, et al. (2012) Evolution of HIV-1 genotype in plasma RNA and peripheral blood mononuclear cells proviral DNA after interruption and resumption of antiretroviral therapy. Antivir Ther 17 : 577-583.

52. Tang MW, Shafer RW (2012) HIV-1 antiretroviral resistance: scientific principles and clinical applications. Drugs 72: e1-25.

53. Bercoff DP, Triqueneaux P, Lambert C, Oumar AA, Ternes AM, et al. (2010) Polymorphisms of HIV-2 integrase and selection of resistance to raltegravir Retrovirology 7: 98.

54. Temereanca A, Ene L, Duiculescu D, Ruta S (2011) Major HIV resistance mutations in untreated Romanian patients. J Med Life 4: 151-157.

55. Pingen M, Nijhuis M, de Bruijn JA, Boucher CA, Wensing AM (2011) Evolutionary pathways of transmitted drug-resistant HIV-1. J Antimicrob Chemother 66: 1467-1480. 